\title{
METHOD ACCEPTED - FIELDS OF ACTION FOR INCREASING METHODS APPLICATION IN PRODUCT DEVELOPMENT
}

\author{
Wallisch, Anne; \\ Nicklas, Simon J.; \\ Paetzold, Kristin \\ Bundeswehr University Munich
}

\begin{abstract}
Contrary to all agreement that methods can efficiently support design activities in the product development process, it can still be heard that notably complex methods often find little acceptance in industrial practice in terms of consistent use. Therefore, this concept paper aims to identify factors influencing the formation of acceptance to support a successful design and implementation of methods in product development. For this purpose, the first necessary step is to clarify the conceptualization of acceptance within this domain. Furthermore, the influencing variables, which are described in the acceptance models having been identified as development-relevant in a literature review, are first extracted and second newly structured using a behavioural model reflecting the mental stages from stimulus to behaviour. Third, the insights gained towards the factors' relevance throughout these stages are applied to the conditions of method application in engineering and design. In a subsequent step, basic assumptions towards central fields of action for concrete measures to increase acceptance concerning the use of methods in product development are derived.
\end{abstract}

Keywords: Acceptance theory, Design methods, Design theory, Human behaviour in design, Method application

\section{Contact:}

Wallisch, Anne

Universität der Bundeswehr München

Institute for Technical Product Development

Germany

anne.wallisch@unibw.de 


\section{INTRODUCTION}

A central concern of product development research is the provision of methods to support typical development tasks in industrial practice: the scientifically based preparation of findings concerning problem-solving lays the foundations for efficient development. However, methodological research shows that many methods fail to achieve this goal in practice because they are not used altogether (Birkhofer et al., 2015). In this context, a term repeatedly used without experiencing a more profound differentiation is that of acceptance. Without differentiated conceptualization, however, it does not open up any room for maneuvers: Following the observation that some engineers use neither a specific nor any development methods (Eisenmann and Matthiesen, 2020; Gausemeier, 1999) with the conclusion that they do not accept these is not helpful at all in terms of changing the behaviour observed. That fore, it is necessary to identify especially those aspects of method application that seem lacking acceptance, and understand why, and because of which conditions, this is the case.

Although acceptance research is a widely diversified field, basic research on method acceptance is widely absent. This may explain why, in the context of product development, the concept lacks a clear definition. In general, the term acceptance refers to a more or less approving attitude of an individual towards an artefact (Fishbein and Ajzen, 1975; Hilbig, 1984). Regarding the implementation of new technologies, this corresponds to the absence of resistance to the changes considered, more rarely also their benevolent toleration by potential users (Davis, 1985; Petermann and Scherz, 2005). In the context of implementing new methods, however, acceptance usually is equated with their actual application and thus clearly located at the level of action. Against the background of attitude and behaviour being two levels that may be transverse, this might cause misunderstanding. Existing instruments for measuring acceptance under certain circumstances may assess the acceptance of a method as a highly positive attitude towards this method, without this having a significant influence on the actual behaviour.

In order to sensitize for this and other possible pitfalls, by transferring central findings from acceptance research to the specific context of product development, this contribution aims to gain a deeper understanding towards

- the characteristics of the (non-)acceptance of a method, and

- the structural elements determining method acceptance.

After a brief introduction of the research design in the next section (2), the results of acceptance research that have been identified as relevant are first descriptively analysed for a differentiated understanding of the concept of acceptance (section 3). The synthesis of these findings with framing conditions of method application in product development reveals first hints on starting points for measures that are suitable for supporting the formation of acceptance (section 4). Finally, these condense into four fields of action, which are to look at under the assumption that each field requires accordingly specific measures (section 5). Eventually, a summary with an outlook on empirically necessary further steps is given.

\section{RESEARCH APPROACH}

The starting point for the research process, organized in three phases (see Figure 1), was the question to what extent findings from acceptance research can help to understand the concept and the formation of method acceptance. An extensive literature review, performed as structured analysis in a 4-step procedure (analysis of the abstracts, repetition of the keyword search win the continuous text, context analysis of the hits, content analysis of the document) tapped access to the subject and field of acceptance research. The scientific databases Scopus and Mendeley served as data sources.

Following the consideration that other disciplines may use different terms for method acceptance as a research phenomenon, the authors initially decided on an unfiltered search for the term "acceptance" and its German equivalent ("Akzeptanz"), resulting in 1832 hits via Mendeley and 766 via Scopus. By extending the search terms to include product development-related specialist domains and target contexts, the hit base narrowed down to 464 results. After the first review for relevance, 127 contributions remained, and after checking for novelties, 70 contributions remained as a starting point for an additional source analysis concerning explanation models towards acceptance in a technical environment. The resulting final database of this research contains 33 acceptance models (see appendix). 


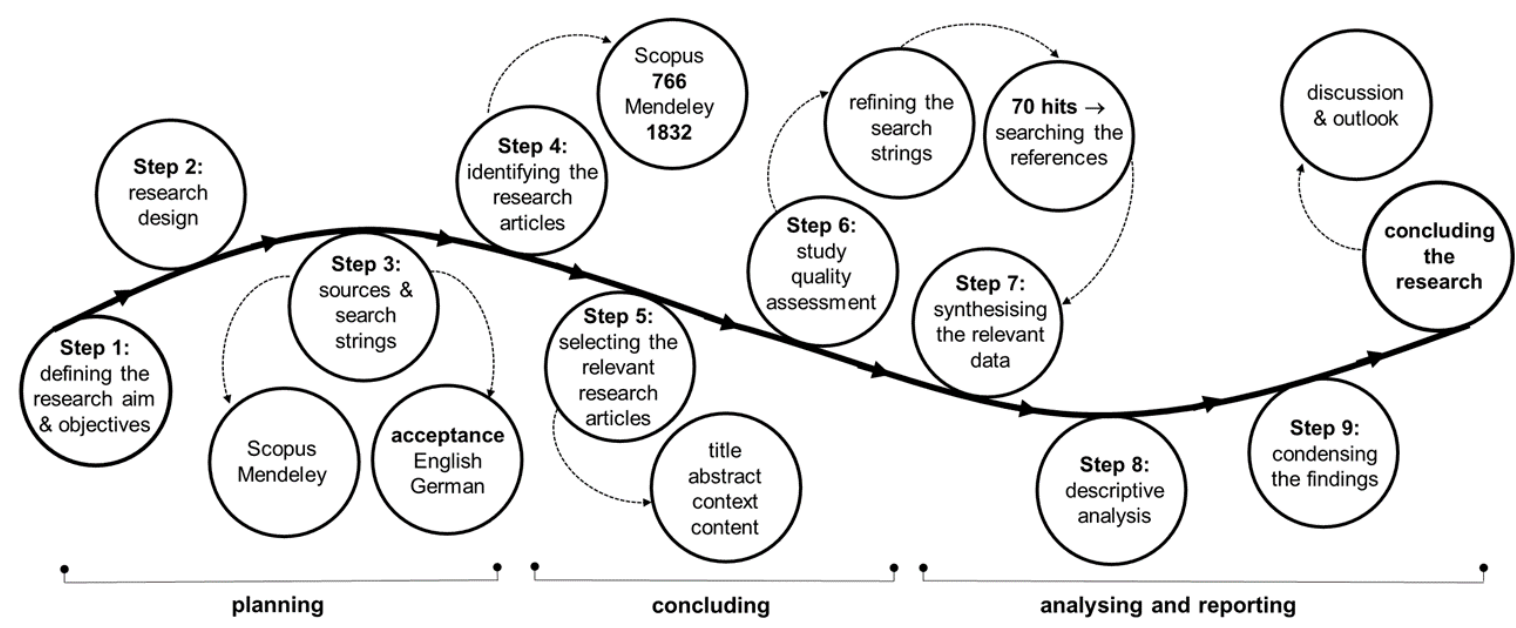

Figure 1. Research process

An in-depth analysis examined these models regarding their underlying definition of acceptance, its subjects, objects, and contexts, research objectives, and the influencing factors identified. In order to be able to structure and assess these factors concerning their relevance for method application in product development, relevant factors, extracted from the original models, underwent reassembling through the assignment to the mental process steps from attitudes to behaviour.

\section{DETERMINANTS OF ACCEPTANCE}

Instead of groundwork research on 'method acceptance', this analysis identified acceptance studies for plenty of specific subjects. The first acceptance models were driven and further developed from psychology and the humanities, and finally adapted and refined to their respective contexts and subjects by other disciplines.

The in-depth analysis proved a different scope of the concept of acceptance among the models. Within those models addressing a voluntary usage context, the acceptance of an artefact is at least implicitly described as equivalent to a corresponding usage behaviour or a preceding usage intention mostly (e.g. Robey, 1979; Thompson et al., 1991). However, other approaches concretely distinguish between the attitude of the acceptor and his or her observable behaviour (e.g. Venkatesh and Bala, 2008; Venkatesh and Davis, 2000). In this context, Eagly and Chaiken (1993) refer to an attitude as a psychological reaction tendency that leads to assessing a particular object with a certain degree of affection or rejection. Any stimulus that allows for an evaluation can also be the subject matter of an attitude (Haddock and Maio, 2007; Bagozzi et al., 1992). If at all, attitudes and behaviours are most likely to correspond with each other when both are very specific and correlate in the four aspects of action, object, context, and time (Ajzen and Fishbein, 1977), but they are even more likely not to correspond. The most general reason for this discrepancy relates to the situational context: if there is a difference between the situations in which attitude and behaviour are respectively measured, deviations are to be expected (Wicker, 1969).

The question of whether future behaviour is predictable, and if so, how, is the scope of the theory of reasoned action (TRA, Fishbein and Ajzen 1975). This theory describes attitudes based on three components: beliefs, as judgments about truth or probable correlations, based on an emotionalaffective reaction or reactive-rational judgement, which can manifest themselves as a predisposition to action within an attitude, attitudes, and behavioural intentions. The authors use these components to structure the analytically extracted factors influencing acceptance formation, without assuming, however, that a behavioural intention necessarily also results in behaviour. Overall, the structuring done here does not rely on the model-theoretical assumptions of the TRA but uses the given granularity in the description of attitudes through its components. In this conceptualization, the elements gestate an ideal-typical linear process that allows for assigning the influencing variables of the analysed acceptance models according to their conditions of effect. This assignment facilitates an abstracted mapping of the ranges of the epistemic horizons of the models, and thus, the evaluation of their general relevance for the explanation of method application in product development.

The corresponding visualization (Figure 2) spans the description of the relevant contexts and contextual factors that already predetermine with which affective reactions or cognitive assessments 
an acceptor is likely to react to a stimulus, in this case, the development method. These beliefs manifest themselves through the acceptor's perceptual and evaluative process as a behavioural disposition of an attitude. The subjective norm perceived by him or her in this regard affects the decision of an intention to act, and the actual subjective norm finally affects the decision-making process regarding a particular behaviour. The subjective norm, as an element of TRA, describes both: the beliefs that an individual holds regarding the behaviour expected of him or her, and the extent of his or her willingness to comply with this normative pressure.

Figure 2 quantitatively and qualitatively reflects that most of the models focus on the attitudinal dimension of acceptance: Not only are the factors influencing beliefs the most frequently studied (60 times), but they also show the highest degree of elaboration. The factors identified as being context determining or respectively as predispositions determined by the context indicate that the authors' search scheme adequately covers the scope of the study: the underlying data basis examines influences in terms of not only the overall living context but also the specific professional sub-context. Moreover, the influencing factors described in this context allow further differentiation into such being more task-specific as well as those being more organization-specific. To control for unconsciously preassumptions biasing the authors' assigning decisions within the process, factors to be assigned were allocated randomly and blindly to each author. The results of these assignment processes firstly were merged through communicative validation and finally analysed concerning recognizable patterns.

Influencing factors concerning the emotional component of beliefs are collected 16 times into a structural category. In some models, this affective response is further differentiated into concrete manifestations while in others it is examined as an accumulated measure. Concerning the evaluation of this finding, one must take into account that affective responses happen unconsciously and uncontrollably so that corresponding studies are both complex and susceptible to interference. On the other hand, some models actually do not refer to the emotional aspects of attitudes, which means they do not analyse the factors influencing them.

The rational component of beliefs manifests itself 44 times in factors that can determine the cognitive assessment, and influence the acceptor's attitudes towards an object of acceptance through both the living and the professional contexts' determinants. The general living context can influence behaviour, especially through normative and control beliefs, in that a socially shared understanding of acceptability pre-structures all areas of action accordingly. The determinants of the professional context mainly are explained in terms of their influence on beliefs that can be classified as 'situational'. The behavioural component of attitudes was considered the least among the acceptance models studied: The influences on attitudes towards use analysed in 11 cases were mainly explained as a summarized-aggregated structural category, for which only one characteristic, the "acceptance of the solution proposed", was described in more detail. This emphasizes the qualitative difference between the behavioural dimension of an attitude and a clear behavioural intention by the fact that the former is already considered fulfilled if the acceptance object does not receive a negative evaluation, even if no action tendency for a reaction is recognizable.

The influencing factors being described 20 times as affecting the behavioural intention are mostly referred to only as a certain intention to use. Those, being described in their specific manifestations, again address affective, behavioural, and cognitive components of the intended behavioural tendencies. At the same time, they provide indications regarding the acceptor's actual scope of action, which seems to increase significantly when using a component-based approach to conceptualizing acceptance as opposed to its dichotomous approach. Finally, acceptance in the sense of concrete behaviour was not further described, but merely summarized as a structural category of behaviour, that of utilization, which is decided depending on the behaviour of others. Solely once utilization was explained more concretely as the pursuit goal to social adaptation.

Summarizing and transferring these findings to product development, the authors conclude that acceptance towards methods refers specifically to phenomena in the vocational context and should not be applied to describe experiences limited to the emotional stance of a human being. Moreover, acceptance towards methods is complex. People oversimplify the concept of method acceptance when they only focus on method application or refusal because of individual characteristics. However, central factors driving acceptance are found in the engineer's workplace environment, how his or her boss leads, the quality of their own team, and even macro-level issues like changing industry regulations that shift organizational priorities, which influence how leaders lead their teams, which then impacts how frontline engineers work. 


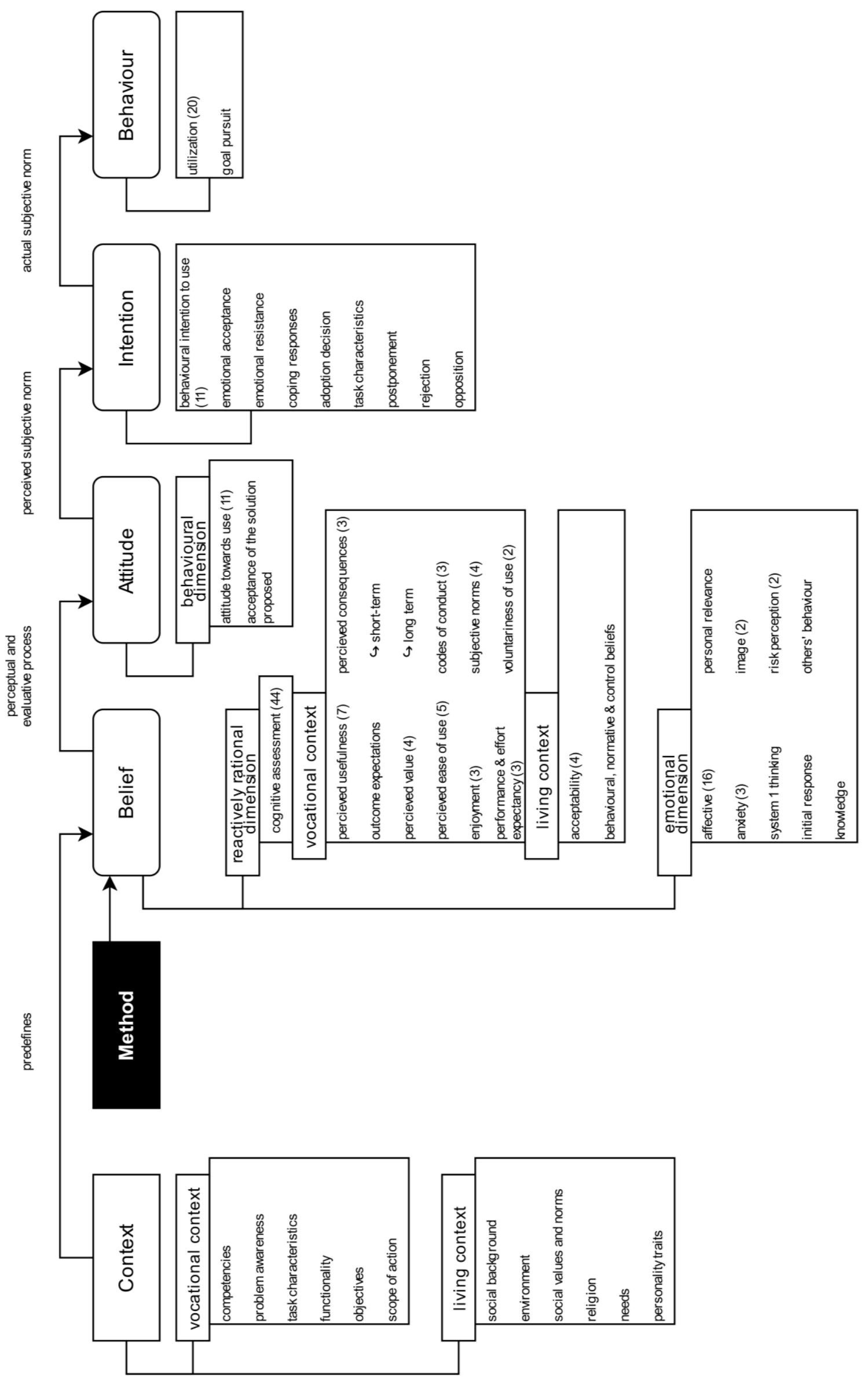

Figure 2. Relation of context, attitudes and behaviour: findings from acceptance research 


\section{IMPLICATIONS FOR PRODUCT DEVELOPMENT}

The observation and feedback from Industry that development methods are only occasionally deployed in practice is critical in two directions: On the one hand, implicit employee knowledge is not directly available to the company, but only where implicit knowledge is made explicit new knowledge can emerge. On the other hand, the human cognitive capacity is limited and its ability to make decisions is hampered by errors of judgement. Hidden gaps in knowledge and experience can, however, be controlled and overcome by the application of development methods, meaning that method acceptance in the context of product development must be conceptualized as an active willingness to participate in the sense of the targeted behaviour.

When complaining about a lack of acceptance of methods, this implicitly refers to the engineering designers' lack of method application while performing their tasks. Here, the development method is the object of acceptance, to which the so-called "subject of acceptance", the engineering designer, has a certain attitude. The acceptance context in the broadest sense is then the company or organization in which the engineering designer is working and which shapes his or her professional environment by its very own standards, structures, and expectations. Under the premise that the method application customized to the situation achieves the most benefit in product development, the authors additionally distinguish the acceptance context in a narrower sense. Under this context, they understand the engineering designer's direct workaround, which is characterized by specific tasks, their characteristics and the corresponding activities.

An activity principally represents a system with its very own structure, which can act as a mediating instance between object and subject (Leontjew, 1978). In his activity, a human being therefore actively engages with his or her environment and then manipulates it according to his or her goals. Likewise, occupational activity constantly changes personality and environment through creation and adaptation as well as feedback and reflection, which explains why people can continually learn and develop new skills and abilities in the course of their professional work (Frieling and Sonntag, 1999). The following figure (Figure 3) provides a schematic illustration of the interplay between the subject of acceptance, acceptance object, and the acceptance context regarding the present object of investigation.

Especially the overcoming of the dichotomous conceptualization of acceptance deserves special attention. Thus, a positive acceptance does not always have to result in a positive outcome on the behavioural level: if, for example, the tolerating willingness of acceptance subjects leads them to spend resources in terms of time and cost to learn a method that has no relevance to their specific tasks, this will not be profitable. It gets even worse, if the indifferent application of a method without necessary adaptation may even result in a decrease in quality; these manifestations of method acceptance prevent their value-creating character. This addresses a qualitative dimension of acceptance, which is considered being meaningful in the context of product development.

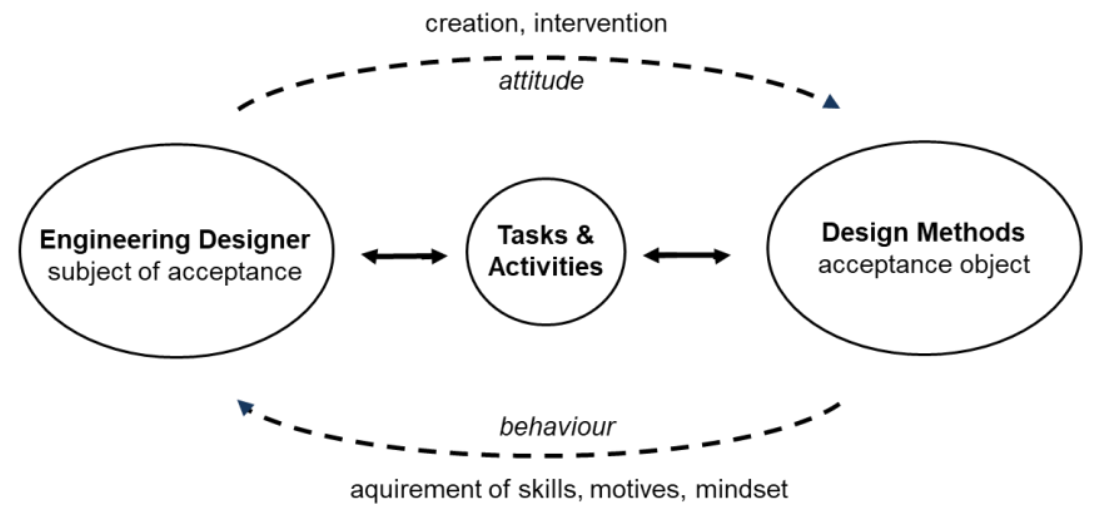

Figure 3. Acceptance context in engineering design (based on Frieling and Sonntag, 1999)

In summary, acceptance research offers both structurally content-related and temporally logical model elements that help to explain the employment of methods according to their boundary conditions. These elements require a precise adaption to the concrete object of product development in order to contribute further to theory generation there. Based on the considerations made, the authors propose the following definition for method acceptance in the product development context: Method 
acceptance in product development describes the designated user's attitude towards a certain behavioural intention in the scope of method application, which can manifest itself in different behavioural characteristics on a continuum between willingness and rejection. Hereby, they assume the behavioural intention is indicating actually observable behaviour, but by designing the relation between willingness and rejection continuous instead of dichotomy, this assumption is not of deterministic nature. Furthermore, an empirical finding of no relationship at all is considered by the merely optional integration of a behavioural response. At the same time, this optionality offers the scope of influencing an individual's assessment of a behavioural intention and thus a targeted behaviour by means of employing suitable measures.

The suitability of measures particularly depends on the organizational and task-related context, which conditions should be examined first. In order for organizations to reduce refusal towards method application, they must address the causes of it (and apply systemic remedies). Acceptance refusal is caused by an imbalance between one's job demands (aspects of one's work that take consistent effort and energy) and job resources (aspects of one's work that are motivational and sense-giving), and there are some core job demands that organizations, leaders, and teams need to reduce in order to decrease the likelihood of method refusal. Overall, high workload and pressure (particularly problematic in combination with too few resources) hinder willingness to learn new procedures, which is the same for values disconnection (what one finds important about work does not match the environment he or she is in) and a lack of recognition (appreciating feedback towards the challenges and efforts in learning new things is missing). These are organizational issues, which cannot be explained by or fixed with individual beliefs and attitudes without referring to their context of origin.

\section{FIELDS OF ACTION FOR ACCEPTANCE INCREASING MEASURES}

In the context of this paper, acceptance was elaborated as a multi-factorial concept, so for some circumstances, it might be challenging to identify existing barriers and respond appropriately to increase method acceptance. Based on their analysis results, in this respect, the authors conclude that it will be useful not to start immediately and solely with the designated user to look at. In contrast, they emphasize to describe first the situation as a use case in its basic conditions of the narrower and broader acceptance context, the characteristics of the acceptance object and the dispositions of the acceptance subject in different scenarios and to disclose interactions.

The (voluntary) decision to employ development methods is linked to a corresponding need or a certain result expectation. Depending on the conditions under which rejection tendencies towards method acceptance have manifested themselves, countermeasures are particularly suitable for increasing acceptance if they correspond as closely as possible to these conditions in the opposite direction. The same applies to the endeavour to make successfully influenced behavioural intentions persistent in behaviour. In the context of the investigation, the accordance of the four aspects action, object, context and time (Ajzen and Fishbein, 1977) was mentioned as critical for success.

Resulting from content and context of work being interrelated and contributing differently to the formation of needs or expectations, the authors concluded that classifying the possible influencing factors according to those that relate to the occupational content and those that relate to the occupational context correspond to the conception of the wider context and the narrower context (related occupational activities). The temporal aspect is immanent to the engineering designer as far as his or her attitude towards a behaviour is usually only considered when it is subject to change. Finally, the aspect of the object concerns the development methods, which must necessarily correspond in their operative character and thus rules of action in order to determine an acceptance problem in the first place. Acceptance measurements, which reveal the existing knowledge, understanding and the underlying willingness to act with regard to corresponding methods and tools in the company already before and during the method decision or its development, can offer central starting points for a successful design of methods and their implementation. This results in four fields of action in which different measures can be taken to increase acceptance: concerning the method itself, its designated user, his or her occupational activity as a use case for the method, and the organization as structuring the entire application context.

Method. Measures that relate to an increase in acceptance towards a particular development method already begin with the development of the method, which ideally takes place based on corresponding process analyses or required demands. One of the key instruments of quality assurance 
is method validation in the sense that this finally proves that a method is actually suitable to fulfil a defined task. Depending on the method to be validated, the first step is to determine the parameters of the validation. Acceptance-increasing measures should base on the consideration of aspects concerning the usability of the method and its perceived usefulness towards the expected outcomes in the first place. This includes keeping people informed of changes by providing a rationale or explanation for projects, goals, and big-picture vision from the very beginning. Making constructive feedback a learning-focused, two-way conversation is contributing a requirements analysis aimed at minimizing conflicting requests and ambiguity (two known accelerants of denial), and, therefore, supporting successful method implementation while its development already.

User. The critical observation of a lack of acceptance towards the application of methods is often justified somewhat succinctly by the fact that development engineers prefer to rely on their experience and intuition. The understanding of an activity as a contribution to personality development identified in the course of this study can explain on the one hand that certain stability in attitude can de facto be expected here, and at the same time offers indications for overcoming it. Persuasive communication addressing the user's existing fears or goals and situational-individual training sessions tailored to his or her learning needs and qualifications to increase his or her methodological competence were identified as increasing acceptance. In industrial practice, however, these individual characteristics seem to be taken into account just as rarely as the conditions of its wider context and situational appropriateness (Albers et al., 2014; Eisenmann and Matthiesen, 2020).

Occupation. The conditions under which a method is to be applied must always be given adequate consideration when considering acceptance. Thus, the acceptance-critical moment may be less the considered acceptance subjects themselves, but rather uncertainty and lack of communication of their superiors, colleagues forming data silos or neighbouring departments torpedoing the process chain. The timely skimming off-task knowledge, as well as criteria of workplace and work equipment design, is crucial to successful method development. A participatory method development through the appropriate involvement of the users is indirectly already a measure with a high acceptance-forming function. Related to this, it is important to clarify confusing and missing information related to roles and tasks. Offering in-time feedback to peers and direct reports as well as being clear when giving assignments and encouraging team members are other, rather small, interventions to involve people with a reasonable impact on towards their engagement, however.

Context. Following Rogers (1962), the developmental organization is understood here as a system of decisions whose regulatory framework is communication, which structures both individual behaviours and the organizational environmental conditions in a reciprocal manner. A central argument for conviction, however, the success of the use of methods, is often lost in product development because the corresponding measurement is missing. Acceptance-building measures concerning the organization include the support of change processes by the management as well as the establishment of a corresponding error culture, which facilitates the overcoming of dichotomously organized behavioural dispositions and makes the intended behaviour more likely overall. The behaviour-influencing effect of the orientation towards the subjective norm, which was elaborated in the course of the analysis, also suggests that the establishment of standardized processes with the same level of commitment for all company members has a positive effect on method acceptance.

\section{SUMMARY AND OUTLOOK}

The overall goal of the paper was to identify conditions for acceptance formation that supports the successful design of methods and their implementation in product development. For this purpose, a literature review on acceptance research examined the acceptance models identified as relevant for development with regard to their influencing variables, extracted these and applied them to the field of product development. Four central fields of action were identified as starting points for acceptanceincreasing measures. Hereby, the guiding question is how to transfer a behavioural intention into concrete behaviour. Acceptance towards methods is not an interchangeable term with general methods' application. Acceptance exists on a continuum and becomes something more like refusal when one experiences lacking usefulness, ease of use, and value, for example.

To allow reliable conclusions for product development, however, the empirical verification of the results described is necessary. With this goal in mind, the research is currently in its field phase, which is conducting qualitative semi-structured interviews with selected industry representatives. The first 
question, whether the influencing variables from acceptance research dealt with here also empirically prove relevant for method acceptance in product development towards specific situations of interest, clearly seems to be answered with "yes", so far. Within the next steps, these development situations are to be understood concerning the occurrence of different characteristics of acceptance and described in their contextual constraints. Identified correlation patterns are to be assessed with regard to their predictability, and in doing so or in addition, hypotheses on the cause-and-effect relationships for phenomena of acceptance formation are to be derived and again empirically tested. This includes a more precise understanding of the cause-and-effect relationships among the constitutive fields of action, from which finally strategic decisions regarding successful acceptance management can be derived. These results should ultimately condense into a process modelling that maps the entire workflow of the presentation, recording, internalization, application and adaptation of method management and thus provides situation-appropriate recommendations for action to increase the method application.

\section{ACKNOWLEDGMENTS}

This research work is part of "FORCuDE@BEV - Bavarian research association for customized digital engineering for bavarian SMEs" and funded by the "Bayerische Forschungsstiftung (BFS)". The authors are responsible for the content of this publication. Special thanks are directed to the Bayerische Forschungsstiftung (BFS) for financial support of the whole research project.

\section{REFERENCES}

Ajzen, I. and Fishbein, M. (1977), “Attitude-behavior relations: A theoretical analysis and review of empirical research", Psychological Bulletin, 84, pp. 888-918.

Albers, A., Reiß, N., Bursac, N., Urbanec, J. and Lüdcke, R. (2014), "Situation-appropriate method selection in product development process - empirical study of method application”, in Proceedings of NordDesign 2014 Conference, Aalto Design Factory, pp. 550-559.

Bagozzi, R., Davies, F.D. and Wahrshaw, P. (1992): "Development and Test of a Theory of Technological Learning and Usage”, Human Relations, Vol. 45 No. 7, pp. 659-686.

Birkhofer, H., Jänsch, J. and Kloberdanz, H. (2005): "An extensive and detailed view on the application of design methods and methodology in industry", in Samuel, A. and Lewis, W. (Eds), DS 35: Proceedings ICED 05, 15th International Conference on Engineering Design, Melbourne, Australia, Design Society, 2005, pp. 276-277

Davis, F.D. (1985), “A Technology Acceptance Model for Empirically Testing New End-User Information Systems: Theory and Results", PhD Thesis, Massachusetts Institute of Technology.

Eagly, A.H. and Chaiken, S. (1993), "The psychology of attitudes", Fort Worth, TX, Harcourt Brace Jovanovich.

Eisenmann M. and Matthiesen, S. (2020), "Idetifying reasons for a lack of method application in engineering design practice - an interview study”, in DESIGN2020, Vol. 1 Design Society, pp 2495-2504.

Fishbein, M. and Ajzen, I. (1975), "Belief, Attitude, Intention, and Behavior: An Introduction to Theory and Research", Addison-Wesley Pub. Co, Reading, Mass.

Frieling, E. and Sonntag, K. (1999), “Arbeitspsychologie”, 2nd Edition, Verlag Hans Huber, Bern.

Gausemeier, J. (1999), Kurzbericht über die Untersuchung Neue Wege zur Produktentwicklung: eine Untersuchung im Rahmenkonzept “Produktion 2000”, 2. Ed., Heinz-Nixdorf-Institut, Paderborn, Univ.-GH Paderborn.

Haddock, G. and Maio, G. (2007), “Einstellungen: Inhalt, Struktur und Funktionen”, in K. Jonas, W. Stroebe and Hewstone, M. (Eds), Sozialpsychologie, Springer, Wiesbaden, pp. 188-223.

Hilbig, W. (1984), “Akzeptanzforschung neuer Bürotechnologien. Ergebnisse einer empirischen Fallstudie”, Office Management, Vol. 32 No. 4, pp. 320-323.

Leontiev, A. N. (1978), Activity, consciousness, and personality, Englewood Cliffs, NJ, Prentice Hall.

Petermann, T. and Scherz, C. (2005), "TA und (Technik-)Akzeptanz(-forschung)", Technikfolgenabschätzung - Theorie und Praxis, Vol. 14 No. 3, pp. 45-53.

Robey, D. (1979), "User Attitudes and Management Information System Use", Academy of Management Journal, Vol. 22 No. 3, pp. 527-538. https://doi.org/10.2307/255742

Rogers, E.M. (1962), Diffusion of Innovations, Free Press, New York.

Thompson, R.L., Higgins, C.A. and Howell, J.M. (1991), "Personal Computing: Toward a Conceptual Model of Utilization", MIS Quarterly, Vol. 15 No. 1, pp. 125-143.

Venkatesh, V. and Bala, H. (2008), "Technology Acceptance Model 3 and a Research Agenda on Interventions”, Decision Sciences, Vol. 39 No. 2, pp. 273-315.

Venkatesh, V. and Davis, F.D. (2000), "A theoretical extension of the technology acceptance model: Four longitudinal field studies”, Management Science, Vol. 46 No. 2, pp. 186-204.

Wicker, A. W. (1969), "Attitudes versus actions: The relationship of verbal and overt behavioral responses to attitude objects”, Journal of Social Issues, Vol. 25 No. 4, pp. 41-78. 


\section{Data basis of the research presented}

\begin{tabular}{|c|c|}
\hline MODEL & SOURCE \\
\hline $\begin{array}{l}\text { Theory of Planned Behavior } \\
\text { (TPB) }\end{array}$ & $\begin{array}{l}\text { Ajzen, I. (1985), "From Intentions to Actions: A Theory of Planned Behavior", in Kuhl, J. and Beckmann, J. } \\
\text { (Eds.), Action Control: From Cognition to Behavior, Springer Berlin Heidelberg, Berlin, Heidelberg, pp.11-39. }\end{array}$ \\
\hline TPB 2 & $\begin{array}{l}\text { Ajzen, I. and Madden, T.J. (1986), "Prediction of goal-directed behavior: Attitudes, intentions, and perceived } \\
\text { behavioral control", Journal of Experimental Social Psychology, Vol. } 22 \text { No. } 5 \text {, pp. } 453-474 .\end{array}$ \\
\hline $\begin{array}{l}\text { Dynamic Acceptance Model } \\
\text { for the Re-evaluation of } \\
\text { Technology based } \\
\text { Applications (DART) }\end{array}$ & $\begin{array}{l}\text { Amberg, M., Hirschmeier, M. and Schobert, D. (2003), "DART - Ein Ansatz zur Analyse und Evaluierung der } \\
\text { Benutzerakzeptanz, in Uhr, W., Esswein, W. and Schoop, E. (Eds.), Wirtschaftsinformatik 2003: Medien - } \\
\text { Märkte - Mobilität, Physica-Verlag, Heidelberg. }\end{array}$ \\
\hline $\begin{array}{l}\text { Acceptance Model for Driver } \\
\text { Assistance Systems }\end{array}$ & $\begin{array}{l}\text { Arndt, S. (2011), Evaluierung Der Akzeptanz von Fahrerassistenzsystemen: Modell Zum Kaufverhalten von } \\
\text { Endkunden, 1st ed., VS, Wiesbaden. }\end{array}$ \\
\hline $\begin{array}{l}\text { Model for Consumer } \\
\text { Resistance to, and } \\
\text { Acceptance of Innovations }\end{array}$ & $\begin{array}{l}\text { Bagozzi, R.P. and Lee, K.-H. (1999), "Consumer Resistance To, and Acceptance Of, Innovations", edited by } \\
\text { Arnould, E.J. and Scott, L.M., Advances in Consumer Research, Vol. 26, pp. 218-225. }\end{array}$ \\
\hline $\begin{array}{l}\text { Medical Technology } \\
\text { Acceptance Model }\end{array}$ & $\begin{array}{l}\text { Brukamp, K. (2011), "Akzeptanzfaktoren für die ambulante Telemedizin", in Brukamp, K., Laryionava, K., } \\
\text { Schweikardt, C. and Gross, D. (Eds.), Technisierte Medizin - Dehumanisierte Medizin? Ethische, Rechtliche } \\
\text { Und Soziale Aspekte Neuer Medizintechnologien, Vol. 1, Kassel University Press, Kassel, pp. 71-76. }\end{array}$ \\
\hline $\begin{array}{l}\text { Model for Computer Self- } \\
\text { Efficacy }\end{array}$ & $\begin{array}{l}\text { Compeau, D.R. and Higgins, C.A. (1995), "Computer Self-Efficacy: Development of a Measure and Initial } \\
\text { Test", MIS Quarterly, Vol. } 19 \text { No. 2, pp. 189-211. }\end{array}$ \\
\hline Motivational Model & $\begin{array}{l}\text { Davis, F.D., Bagozzi, R.P. and Warshaw, P.R. (1989), "User Acceptance of Computer Technology: A } \\
\text { Comparison of Two Theoretical Models", Management Science, Vol. } 35 \text { No. 8, pp. 982-1003. }\end{array}$ \\
\hline $\begin{array}{l}\text { Technology Acceptance } \\
\text { Model (TAM) }\end{array}$ & $\begin{array}{l}\text { Davis, F.D. (1985), A Technology Acceptance Model for Empirically Testing New End-User Information } \\
\text { Systems: Theory and Results, PhD Thesis, Massachusetts Institute of Technology. }\end{array}$ \\
\hline $\begin{array}{l}\text { Acceptance Model for Screen } \\
\text { Text }\end{array}$ & Degenhardt, W. (1986), Akzeptanzforschung Zu Bildschirmtext: Methoden u. Ergebnisse, Fischer, München. \\
\hline $\begin{array}{l}\text { Social Acceptance and } \\
\text { Rejection Theory }\end{array}$ & $\begin{array}{l}\text { DeWall, C.N. and Bushman, B.J. (2011), "Social Acceptance and Rejection: The Sweet and the Bitter", } \\
\text { Current Directions in Psychological Science, Vol. } 20 \text { No. 4, pp. 256-260. }\end{array}$ \\
\hline Combined TAM with TTFM & $\begin{array}{l}\text { Dishaw, M.T. and Strong, D.M. (1999), "Extending the technology acceptance model with task-technology fit } \\
\text { constructs", Information \& Management, Vol. } 36 \text { No. 1, pp. 9-21. }\end{array}$ \\
\hline $\begin{array}{l}\text { Dual Process Theory of } \\
\text { Cognition }\end{array}$ & $\begin{array}{l}\text { Evans, J.St.B.T. and Stanovich, K.E. (2013), "Dual-Process Theories of Higher Cognition: Advancing the } \\
\text { Debate", Perspectives on Psychological Science : A Journal of the Association for Psychological Science, } \\
\text { Vol. } 8 \text { No. 3, pp. 223-241. }\end{array}$ \\
\hline $\begin{array}{l}\text { Theory of Reasoned Action } \\
\text { (TRA) }\end{array}$ & $\begin{array}{l}\text { Fishbein, M. and Ajzen, I. (1975), Belief, Attitude, Intention, and Behavior: An Introduction to Theory and } \\
\text { Research, Addison-Wesley Pub. Co, Reading, Mass. }\end{array}$ \\
\hline $\begin{array}{l}\text { Task-Technology-Fit Model } \\
\text { (TTFM) }\end{array}$ & $\begin{array}{l}\text { Goodhue, D.L. and Thompson, R.L. (1995), "Task-Technology Fit and Individual Performance", MIS } \\
\text { Quarterly, Vol. } 19 \text { No. 2, pp. 213-236. }\end{array}$ \\
\hline $\begin{array}{l}\text { Consumer Resistance } \\
\text { Hierarchy }\end{array}$ & $\begin{array}{l}\text { Kleijnen, M., Lee, N. and Wetzels, M. (2009), "An exploration of consumer resistance to innovation and its } \\
\text { antecedents", Joumal of Economic Psychology, Vol. } 30 \text { No. 3, pp. 344-357. }\end{array}$ \\
\hline $\begin{array}{l}\text { Dynamic Acceptance Model to } \\
\text { Usage Innovation }\end{array}$ & $\begin{array}{l}\text { Kollmann, T. (1998), Akzeptanz innovativer Nutzungsgüter und -systeme: Konsequenzen für die Einführung } \\
\text { von Telekommunikations- und Multimediasystemen, Gabler, Wiesbaden. }\end{array}$ \\
\hline Model of User Behavior & $\begin{array}{l}\text { Robey, D. (1979), "User Attitudes and Management Information System Use", Academy of Management } \\
\text { Journal, Vol. } 22 \text { No. 3, pp. 527-538. }\end{array}$ \\
\hline Diffusion Theory & Rogers, E.M. (1962), Diffusion of Innovations, Free Press, New York. \\
\hline $\begin{array}{l}\text { Parental Acceptance- } \\
\text { Rejection (PARTheory) }\end{array}$ & $\begin{array}{l}\text { Rohner, R.P. (1960), Child Acceptance-Rejection and Modal Personality in Three Pacific Societies, } \\
\text { Unpublished Thesis, Stanford University, Stanford. }\end{array}$ \\
\hline $\begin{array}{l}\text { Interpersonal Acceptance- } \\
\text { Rejection Theory }\end{array}$ & $\begin{array}{l}\text { Rohner, R.P. (2016), "Introduction to Interpersonal Acceptance-Rejection Theory (IPARTheory) and } \\
\text { Evidence", Online Readings in Psychology and Culture, Vol. } 6 \text { No. 1, available at: } \\
\text { https://scholarworks.gvsu.edu/orpc/vol6/iss } 1 / 4(02.09 .2020)\end{array}$ \\
\hline $\begin{array}{l}\text { Artificial Intelligence } \\
\text { Acceptance Model (KIAM) }\end{array}$ & $\begin{array}{l}\text { Scheuer, D. (2020), "Entwicklung eines Theoriemodells zur Akzeptanz von Künsticher Intelligenz", } \\
\text { Akzeptanz von Künstlicher Intelligenz: Grundlagen Intelligenter KI-Assistenten Und Deren Vertrauensvolle } \\
\text { Nutzung, Springer Fachmedien Wiesbaden, Wiesbaden, pp. 57-65. }\end{array}$ \\
\hline $\begin{array}{l}\text { Acceptance of Road-Pricing } \\
\text { Measures }\end{array}$ & $\begin{array}{l}\text { Schlag, B. (1998), "Zur Akzeptanz von Straßenbenutzungsentgelten”, Internationales Verkehrswesen, Vol. } \\
50 \text { No. 7/8, pp. 308-312. }\end{array}$ \\
\hline Use-Diffusion Model & $\begin{array}{l}\text { Shih, E.C.-F. and Venkatesh, A. (2004), "Beyond Adoption: Development and Application of a Use-Diffusion } \\
\text { Model", Joumal of Marketing, Vol. } 68 \text { No. 1, pp. 59-72. }\end{array}$ \\
\hline Consumer Perceived Value & $\begin{array}{l}\text { Sweeney, J.C. and Soutar, G.N. (2001), "Consumer perceived value: The development of a multiple item } \\
\text { scale", Journal of Retailing, Vol. } 77 \text { No. 2, pp. 203-220. }\end{array}$ \\
\hline $\begin{array}{l}\text { Acceptance Model of PC } \\
\text { Utilization }\end{array}$ & $\begin{array}{l}\text { Thompson, R.L., Higgins, C.A. and Howell, J.M. (1991), "Personal Computing: Toward a Conceptual Model } \\
\text { of Utilization", MIS Quarterly, Vol. } 15 \text { No. 1, p. } 125 .\end{array}$ \\
\hline $\begin{array}{l}\text { Acceptance Model for IT } \\
\text { Solutions }\end{array}$ & $\begin{array}{l}\text { Triandis, H.C. (1980), "Values, attitudes, and interpersonal behavior", edited by Page, M.M. and Sherif, } \\
\text { C.W.Nebraska Symposium on Motivation 1979: Beliefs, Attitudes, and Values, Vol. 27, pp. 195-259. }\end{array}$ \\
\hline $\begin{array}{l}\text { Unified Theory of Acceptance } \\
\text { and Use of Technology } \\
\text { (UTAUT) }\end{array}$ & $\begin{array}{l}\text { Venkatesh, Morris, Davis and Davis. (2003), "User Acceptance of Information Technology: Toward a Unified } \\
\text { View", MIS Quarterly, Vol. } 27 \text { No. 3, pp. 425-478. }\end{array}$ \\
\hline TAM 3 & $\begin{array}{l}\text { Venkatesh, V. and Bala, H. (2008), "Technology Acceptance Model } 3 \text { and a Research Agenda on } \\
\text { Interventions", Decision Sciences, Vol. } 39 \text { No. 2, pp. 273-315. }\end{array}$ \\
\hline TAM 2 & $\begin{array}{l}\text { Venkatesh, V. and Davis, F.D. (2000), "A theoretical extension of the technology acceptance model: Four } \\
\text { longitudinal field studies", Management Science, Vol. } 46 \text { No. 2, pp. 186-204. }\end{array}$ \\
\hline UTAUT 2 & $\begin{array}{l}\text { Venkatesh, V., Thong, J.Y. and Xu, X. (2012), "Consumer acceptance and use of information technology: } \\
\text { extending the unified theory of acceptance and use of technology", MIS Quarterly, JSTOR, pp. 157-178. }\end{array}$ \\
\hline $\begin{array}{l}\text { Acceptance Model for } \\
\text { Technical Innovations }\end{array}$ & $\begin{array}{l}\text { Wohlfahrt, J. (2004), Akzeptanz und Wirkungen von Mobile-Business-Anwendungen, Dr. Kovač, Hamburg. } \\
\text { (Dynamic Acceptance- and Impact Model for Mobile Business Applications) }\end{array}$ \\
\hline
\end{tabular}

